\title{
Antiulcerogenic effect of Cuphea ignea extract against ethanol-induced gastric ulcer in rats
}

\author{
Amria M. Mousa', Nermin M. El-Sammad', Sherien K. Hassan'', Abd El Nasser A. Madboli², Amani N. Hashim³, \\ Eman S. Moustafa ${ }^{4}$, Sherien M. Bakry ${ }^{3}$ and Elsayed A. Elsayed ${ }^{5,6^{*}}$ (i)
}

\begin{abstract}
Background: Cuphea ignea is one of the herbal resources belonging to Lythraceae family. Some species of this family have been used traditionally in South and Central America's folk medicine for treating stomach disorders. Therefore, the present study was performed to evaluate the gastropreventive effect of aqueous ethanolic extract of C. ignea aerial parts on ethanol-induced gastric ulcer.

Methods: Gastric ulcers were induced in Sprague Dawley rats using one oral dose of absolute ethanol (1.5 mL/rat). The C. ignea aerial parts extract at doses of 250 and $500 \mathrm{mg} / \mathrm{kg}$ body weight and ranitidine (a reference drug) at a dose of $30 \mathrm{mg} / \mathrm{kg}$ body weight were orally administrated daily for 7 days before ulcer induction. One hour after ethanol administration blood samples were collected and then stomachs of sacrificed rats were subjected to biochemical, macroscopic and microscopic studies.

Results: Oral administration of C. ignea extract significantly attenuated gastric ulcer as revealed by significant reduction in the gastric ulcer index and volume of gastric juice while significantly increased preventive percentage, gastric $\mathrm{pH}$ value and pepsin activity. Pre-treatment of $C$. ignea extract markedly improved the serum level of TNF-a, the gastric MPO activity and NO content. Furthermore, C. ignea pre-treatment significantly increased the gastric levels of enzymatic and non- enzymatic antioxidants namely CAT, SOD, GSH-Px, and GSH with concomitant reduction in MDA level compared with those in the ethanol group. These results were further supported by histopathological findings which revealed the curing effect of $C$. ignea on the hemorrhagic shock induced by ethanol toxicity.
\end{abstract}

Conclusions: $C$. ignea extract showed a potential gastroprotective effect on ethanol-induced gastric ulcer, and its effect may be mediated through suppression of oxidative stress and gastric inflammation.

Keywords: Gastric ulcer, Antioxidants, Oxidative stress, Cuphea ignea, Histopathology, Phenolic compounds

\section{Background}

Gastric ulcer is a benign lesion with multiple etiologies, associated with an imbalance between gastric protective factors and aggressive physical, chemical or psychological factors on the mucosal epithelium [1]. These aggressive factors include physical stress, prominent tobacco consumption, alcohol or caffeine, certain types of medications, particularly the non-steroidal anti-inflammatory

\footnotetext{
* Correspondence: eaelsayed@ksu.edu.sa

${ }^{5}$ Bioproducts Research Chair, Zoology Department, College of Science, King

Saud University, Riyadh, Kingdom of Saudi Arabia

${ }^{6}$ Department of Chemistry of Natural and Microbial Products, National

Research Centre, Dokki, Cairo, Egypt

Full list of author information is available at the end of the article
}

drugs and infection by Helicobactor pylori [2]. Among these factors, high alcohol consumption is the greatest cause of gastric mucosal damage [3]. Thus, the experimental model of ethanol-induced gastric ulcer often employed to screen the anti-ulcer compounds [4].

In spite of the domination of synthetic drugs in managing most of human diseases including gastric ulcer, extensive proportion worldwide now directed to traditional medicine [5]. This may be, in part, due to considerable incidence of side effects, drug interactions, microbial resistance and high cost during chemical therapy [6]. Hence, natural products with wide biological activities, better effectiveness and safe profiles are needed to

(c) The Author(s). 2019 Open Access This article is distributed under the terms of the Creative Commons Attribution 4.0 International License (http://creativecommons.org/licenses/by/4.0/), which permits unrestricted use, distribution, and reproduction in any medium, provided you give appropriate credit to the original author(s) and the source, provide a link to the Creative Commons license, and indicate if changes were made. The Creative Commons Public Domain Dedication waiver (http://creativecommons.org/publicdomain/zero/1.0/) applies to the data made available in this article, unless otherwise stated. 
substitute chemical medications [7, 8]. Consequently, there is extensive require for scientific analysis of herbal products with pharmacological effects to discover alternative bioactive phytocompounds [9].

Plants of Lythraceae family are regarded as a valuable source of exclusive natural products for developing medications against various diseases [10]. Cuphea, a new world genus, is considered the largest genera of Lythraceae family [11]. Plants of this genus had been used in the Brazilian folk medicine as an oral contraceptive, hypotensive, diuretic, anti-inflammatory, antipyretic and laxative [12]. Some species of this genus have been used for treating stomach disorders, gonorrhea, syphilis and cancer [13, 14].

Cuphea ignea, cigar plant, is a flowering species in genus Cuphea. It is a tropical, densely branched evergreen subshrub produces tubular, bright red to orange flowers resemble a lit cigar, hence its name. C. ignea is native to Mexico and the West Indies; however, in recent years its popularity is on rise everywhere [15].

So far there are no studies regarding the phytochemistry of C. ignea except Bate-Smith [16] who studied the flavonoids of some Lythraceae plants and reported the presence of quercetin and kaempferol glycosides in $C$. ignea plant. Recently, we isolated from this extract a coumarin with a rare structure, namely, 7-hydroxy 3methoxy coumarin 5 -O- $\beta$-glucopyranoside, which offered potent antioxidant activities in vitro [17]. To date, there is no report proving the biological activity of $C$. ignea in vivo. Therefore, the present study was undertaken to evaluate phytochemical constituents of the aqueous ethanolic extract of $C$. ignea aerial parts and to estimate its gastroprotective effect of $C$. ignea extract against ethanol induced gastric ulcer in rats.

\section{Methods}

\section{Plant collection and extract preparation}

Fresh samples of C. ignea aerial parts were collected from $30 \mathrm{k}$ north Cairo. Authentication of the plant was carried out by Prof. Dr. Salwa Kawashty at the NRC. A voucher specimen was deposited at the herbarium of the NRC (voucher number C 182).The collected C. ignea plant was dried in the shadow, crushed and exhaustively extracted with $70 \%(\mathrm{v} / \mathrm{v})$ aqueous $\mathrm{EtOH}$ under reflux. The obtained eluent was dried under vacuum at 55$60{ }^{\circ} \mathrm{C}$ then dissolved in EtOH. Then, the extract was stored for future use.

\section{Phytochemical screening}

Phytochemical analysis of the aqueous ethanolic extract was carried out as described by Sofowora [18].

\section{Estimation of total phenolic content}

Folin-Ciocalteu method [19] was used to determine total phenolic contents. Briefly, $100 \mu \mathrm{L}$ of the extract was transferred into a test tube and the volume adjusted to $3.5 \mathrm{~mL}$ with distilled water and oxidized with the addition of $250 \mu \mathrm{L}$ of Folin-Ciocalteau reagent. After $5 \mathrm{~min}$, the mixture was neutralized with $1.25 \mathrm{~mL}$ of $20 \%$ aqueous sodium carbonate solution. After $40 \mathrm{~min}$, the absorbance was recorded at $725 \mathrm{~nm}$ against blank. A previously prepared gallic acid-calibration curve was used to deduce the contents of total phenolics using the equation: $y=0.024 x+$ $0.018\left(R^{2}=0.998\right)$, which represented results as gallic acid equivalents.

\section{Estimation of total flavonoids}

Total flavonoid content in the aqueous ethanolic extract of $C$. ignea plant was determined according to Žilić et al. [20] using aluminum chloride assay. Briefly, $300 \mu \mathrm{L}$ of $5 \%$ sodium nitrite was mixed with $100 \mu \mathrm{L}$ of extract. After $6 \mathrm{~min}, 300 \mu \mathrm{L}$ of a $10 \% \mathrm{AlCl}_{3}$ solution was added and the volume was adjusted to $2.5 \mathrm{~mL}$ using distilled water. After $7 \mathrm{~min}, 1.5 \mathrm{~mL}$ of $1 \mathrm{M} \mathrm{NaOH}$ was added, followed by centrifugation $(5000 \mathrm{~g} / 10 \mathrm{~min})$. Absorbance of the supernatant was measured at $510 \mathrm{~nm}$ against the solvent blank. Total flavonoids were estimated using a catachine calibration curve and the equation: $y=0.003 x$ - $0.004\left(R^{2}=0.998\right)$.

\section{Determination of radical scavenging capacity}

The quantitative scavenging of 2,2-diphenyl-1-picrylhydrazyl radical was determined following the Brand et al. method [21]. The extract was dissolved in a concentration of $1 \mathrm{mg} / \mathrm{mL}$ in ethanol. From this stock solution, concentrations of regular dilution were prepared. Then $500 \mathrm{~mL}$ of sample, $375 \mathrm{~mL}$ ethanol and $125 \mathrm{~mL}$ of 1 $\mathrm{mmol} / \mathrm{L}$ prepared scavenging radical solution were placed together. The test was performed in triplicate. After incubation (30 min/dark/room temperature), absorbance was measured at $517 \mathrm{~nm}$ on UV-vis spectrophotometer (Shimadzu, Duisburg, Germany). Ascorbic acid was used as reference standard to conclude the radical scavenging activity percentage (RSA):

$$
R S A \%=\frac{(\text { Control absorbance }- \text { Sample absorbance })}{(\text { Control absorbance })} \times 100
$$

\section{Reducing power assay}

The effect of $C$. ignea extract on the reduction of ferric cyanide into ferrous cyanide was evaluated according to Yen and Duh [22]. A serial dilution of the extract was performed (400, 300, 200, 100, 50, 25 and $12.5 \mu \mathrm{g} / \mathrm{mL})$ in $0.2 \mathrm{M}$ phosphate buffer ( $\mathrm{pH} 6.6)$ containing $1 \%$ ferrocyanate. Tubes containing $5 \mathrm{~mL}$ of the mixture were incubated $\left(50{ }^{\circ} \mathrm{C} / 20 \mathrm{~min}\right)$, followed by addition of $2.5 \mathrm{~mL}$ of $10 \% \mathrm{TCA}(\mathrm{w} / \mathrm{v})$, and then centrifuged $(3000 \mathrm{~g} / 10$ $\mathrm{min})$. The absorbance of the separated supernatant 
(mixed with $2.5 \mathrm{~mL}$ distilled water containing/1\% $\mathrm{FeCl}_{3}$ ) was measured at $700 \mathrm{~nm}$.

\section{Acute toxicity study}

In order to detect the maximal safe dose, Sprague Dawley rat model was used to investigate the effect of $C$. ignea extract on acute toxicity using OECD 425 guidelines [23]. Thirty rats were randomly divided equally into four groups with each group having 5 rats. Groups 1-3 were orally dosed with varying doses $(500 ; 1000 ; 3000$ and 5000$) \mathrm{mg} / \mathrm{kg}$ of C. ignea extract. Group 6 was given an equivalent volume of distilled water. Animals were evaluated clinically and toxicologically for 3 days after receiving the extract, while death rates were monitored for 14 days.

\section{Experimental animals and grouping}

The experiments were performed on adult female Sprague-Dawley rats (150-200 g) obtained from the animal house colony of the National Research Centre, Dokki, Giza, Egypt. The animals were kept in polypropylene cages with wood shaving under standardized animal house conditions (room temperature: $25 \pm 3{ }^{\circ} \mathrm{C}$, $55 \pm 5 \%$ humidity with $12 \mathrm{~h}$ dark/light cycles), fed with standard pellet and allowed free access to water. Distilled water was used for the oral administration of standard drug and plant extracts in all in vivo assays. The animal experiments were conducted according to the international regulations of the usage and welfare of laboratory animals and were approved by the Ethics Committee of the National Research Centre, Cairo, Egypt. Rats were randomized into seven groups $(n=6)$ as follows: Group 1 (normal control rats); Group 2 (ethanol ulcerated rats); Group 3 (ulcerated rats pretreated with reference drug, $30 \mathrm{mg} / \mathrm{kg}$ ranitidine); Group 4 (rats administered only $250 \mathrm{mg} / \mathrm{kg}$ of extract); Group 5 (ethanol ulcerated rats pretreated with $250 \mathrm{mg} / \mathrm{kg}$ of extract); Group 6 (rats were administered only $500 \mathrm{mg} / \mathrm{kg}$ of extract); Group 7 (ethanol ulcerated rats pretreated with $500 \mathrm{mg} / \mathrm{kg}$ of extract). Ranitidine and extract treatments were given orally once/day for 7 days before ulcer induction. Groups 4 and 6 were used to evaluate the negative/toxicological effects of the extract. Groups 2, 3, 5 and 7 were supplied only with water for $24 \mathrm{~h}$ before ulcer induction. A single gavage of absolute ethanol (1.5 $\mathrm{mL} / \mathrm{rat}$ ) was used to induce gastric ulcer after $24 \mathrm{~h}$ fasting according to Liu et al. [4].

Tissue sampling and collection of blood and gastric juice One hour after the ulcer induction, animals were anesthetized by $1.9 \%$ diethyl ether-saturated cotton ball in a small chamber for 2-5 min., and euthanized by cervical dislocation. Blood samples were collected and centrifuged $(3000 \mathrm{rpm} / 10 \mathrm{~min})$, where clear serum was separated and stored at $-20^{\circ} \mathrm{C}$ until analysis. In parallel, animal stomachs were rapidly taken away, opened along the greater curvature, where their contents were collected for volume and $\mathrm{pH}$ determination. The gastric secretion was stored for estimating pepsin activity. Gastric tissue specimens were thereafter rinsed gently with phosphate buffer saline (PBS) to remove any blood clots and then examined macroscopically to calculate gastric ulcer index [6]. Secondly, each stomach was dichotomized, with one moiety of stomach immersed in $10 \%$ formaldehyde for histological examination and the other moiety was homogenized in $0.1 \mathrm{M}$ potassium phosphate buffer, $\mathrm{pH} 7.4$ at a ratio of 1:10 (w/v). The homogenates were centrifuged $\left(3000 \mathrm{rpm} / 10 \mathrm{~min} / 4^{\circ} \mathrm{C}\right)$ using $3-18 \mathrm{KS}$ Sigma cooling centrifuge, Germany. Myeloperoxidase (MPO) activity was detected in the obtained pellets, while supernatants were stored at $-80{ }^{\circ} \mathrm{C}$ for further biochemical investigations.

\section{Estimation of gastric ulcer index}

For each group, ulcer index was determined using the following equation:

$$
\text { Ulcer Index }=\frac{\text { Sum of lesion areas }}{\text { Total stomach area }} \times 100
$$

The percentage of ulcer preventive index was then calculated as follows:

$$
\text { Preventive index }=\frac{\text { Ulcer index }(\text { ulcerated control })-\text { Ulcer index }(\text { treated })}{\text { Ulcer index }(\text { ulcerated control })} \times 100
$$

\section{Estimation of pepsin activity in gastric secretion}

Pepsin activity was determined using stop-point assay of denatured hemoglobin hydrolysis [24].

\section{Biochemical analysis in serum}

Serum aspartate transaminase (AST), alanine transaminase (ALT) and alkaline phosphatase (ALP) activities were determined using commercial kits (Spectrum Diagnostics Company, Egypt). Serum urea and creatinine level were assayed as kidney function tests using kits also provided by Spectrum Diagnostics Company, (Egypt). Serum necrosis factor-alpha (TNF- $\alpha$ ) was investigated by the enzymelinked immunosorbent assay using Koma Biotec Inc. kits, Korea. The operational processes were measured in accordance with the kit instructions.

\section{Biochemical analysis in tissue homogenate Myeloperoxidase activity}

Myeloperoxidase, a marker of neutrophil infiltration, was assayed using a modified method of Bradley et al. [25]. In brief, the pellet from gastric homogenate was resuspended in $50 \mathrm{mM}$ potassium phosphate buffer $(\mathrm{pH}$ 6.0) containing $0.5 \%$ hexadecyl trimethyl ammonium 
bromide using TM 125 tissue master homogenized (Omni, USA). Three freeze/thaw cycles were then performed followed by $10 \mathrm{~s}$ sonication using VCX500 sonicator (Sonics \& materials, Inc. USA). Suspensions were centrifuged $\left(4{ }^{\circ} \mathrm{C} / 15 \mathrm{~min} / 15000 \mathrm{rpm}\right)$, and the supernatant was used to detect MPO activity at $460 \mathrm{~nm}$ using o-dianisidinedihydrochloride and $0.005 \%$ hydrogen peroxide. One unit of MPO activity was defined as that degrading $1 \mu \mathrm{mol}$ peroxide $/ \mathrm{min} / 25^{\circ} \mathrm{C}$.

\section{Nitric oxide assay}

Nitric oxide (NO) concentration was assayed by measuring nitrite formed from NO oxidation [26], based on Griess diazotization reaction.

\section{Catalase assay}

The initial rate of $\mathrm{H}_{2} \mathrm{O}_{2}$ disappearance at $240 \mathrm{~nm}$ was used to detect catalase (CAT) activity according to Aebi [27]. Enzyme activity ( 1 unit) is equivalent to enzyme concentration used to decompose $1 \mu \mathrm{mol}$ of $\mathrm{H}_{2} \mathrm{O}_{2} / \mathrm{min} /$ $25^{\circ} \mathrm{C}$ at $\mathrm{pH} 7.0$.

\section{Superoxide dismutase assay}

Superoxide dismutase (SOD) activity estimated according to method of Minami and Yoshikawa [28], where pyrogallol autoxidation is inhibited through superoxide radical catalysis, reaction with nitro-blue tetrazolium and measurement of formed formazan dye at $540 \mathrm{~nm}$. Enzyme activity (1 unit) is equivalent to enzyme concentration inhibiting $50 \%$ of pyrogallol autoxidation.

\section{Glutathione peroxidase assay}

Glutathione peroxidase (GSH-Px) activity was determined according to method of Necheles et al. [29] at $412 \mathrm{~nm}$. Enzyme activity (1 unit) is equivalent to 1 $\mu \mathrm{mol}$ GSH consumed per minute.

\section{Reduced glutathione assay}

The method of Beutler et al. [30] was used for GSH assay. Tissue homogenate supernatants was previously treated with equal volumes of $10 \%\left(\mathrm{HPO}_{3}\right)_{\mathrm{n}}$, then centrifuged for at least $2 \mathrm{~min}$ at $4000 \mathrm{rpm}$ to eliminate proteins in order to avoid interferences of protein $\mathrm{R}$ SH groups.

\section{Thiobarbituric acid reactive substances assay}

Malondialdehyde (MDA), resulting from lipid peroxidation, was assayed [31] based on the reaction of MDA with amino group of thiobarbituric acid forming 1:2 adduct that absorbs strongly at $532 \mathrm{~nm}$.

\section{Histopathological procedure}

Tissue specimens were taken mainly from the glandular part of stomach of the all groups and fixed in 10\% neutral buffer formalin overnight. Routine tissue processing was carried out according to Suvarna et al. [32]. Tissue blocks were cut into $3 \mu \mathrm{m}$-sections and stained with hematoxylin and eosin $(\mathrm{H} \& \mathrm{E})$ for histopathological examination.

\section{Statistical analysis}

All results were expressed as means $\pm \mathrm{SD}$. The data were evaluated with SPSS 19.0 (SPSS Inc., Chicago, IL, USA). The statistical significance of differences for each parameter among the groups was evaluated by one-way ANOVA, followed by LSD test. The significance level was set at $P<0.05$.

\section{Results}

Phytochemical examination

The qualitative phytochemical screening of aqueous ethanolic extract of $C$. ignea plant revealed the presence of phenolics, flavonoids, tannins, alkaloids, carbohydrates, glycosides, triterpenens and unsaturated sterols. The quantitative phytochemical investigation of total phenolic and flavonoid contents in the extract was shown in Table 1.

\section{Radical scavenging activity of $C$. ignea aerial parts extract} Radical scavenging assay is used to determine the in vitro antioxidant activity of plant extracts. Figure 1 showed the radical scavenging activity of $C$. ignea extract at seven different concentrations ranging from 0.5 to $500 \mu \mathrm{g} / \mathrm{mL}$ (expressed by $\log$ scale) used in comparison with ascorbic acid as standard reference. $C$. ignea extract exhibited nearly similar RSA as ascorbic acid at a concentration of $50 \mu \mathrm{g} / \mathrm{mL}$, the extract completely inhibited the scavenging radical absorbance and give a potent radical scavenging activity with $98 \%$ at concentration of $100 \mu \mathrm{g} / \mathrm{mL}$, indicating a remarkable antioxidant capacity.

\section{Reducing capacity of $C$. ignea aerial parts extract}

The reducing power of phenolic compounds serves as good indicator of its antioxidant activity. Figure 2 showed that $C$. ignea extract had concentration-dependent reducing power. Also, it had an appreciable reducing power when compared to standard quercetin.

\section{Safety of $C$. ignea aerial parts extract}

In this study, no mortality, no important changes in body weight and behavior (ataxia, hypoactivity, and

Table 1 Total phenolic (TPC) and total flavonoid (TFC) contents in C. ignea aerial parts extract

\begin{tabular}{ll}
\hline Total phenols & $121.66 \mathrm{mg} / \mathrm{g}$ \\
\hline Total flavonoids & $105.33 \mathrm{mg} / \mathrm{g}$ \\
\hline
\end{tabular}

TPC is expressed as milligram of gallic acid equivalent per gram of extract. TFC is expressed as milligrams of catachine equivalents per gram of extract 


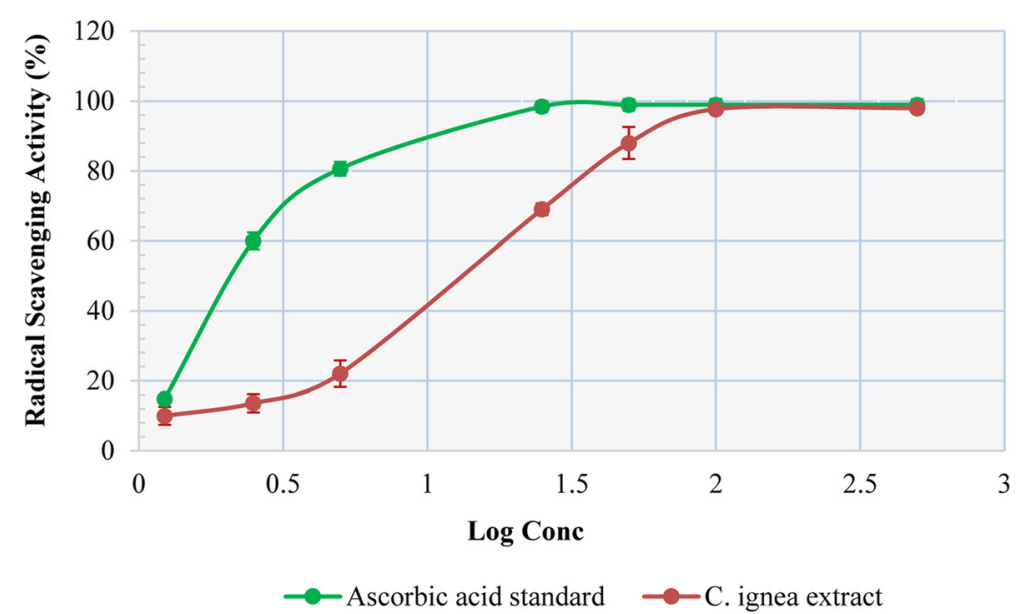

Fig. 1 Radical scavenging activity of C. ignea aerial parts extract in comparison to ascorbic acid. Results are given as mean \pm SD of 3 independent experiments. RSA with $98 \%$ considered as a full absorbance inhibition of scavenging radical because absorbance inhibition of the final solution will never reach $100 \%$

hyperactivity) were observed in rats during the period of $72 \mathrm{~h}$ study up to the maximum dose $(5 \mathrm{~g} / \mathrm{kg}) .250$ and $500 \mathrm{mg} / \mathrm{kg}$ doses of the extract were selected for the antiulcer studies. One week treatment with 250 or $500 \mathrm{mg} / \mathrm{kg}$ of C. ignea extract revealed insignificant changes in the liver and kidney functional tests (Table 2) and recorded irrelevant alterations in all parameters under the present investigation.

\section{Effect of $C$. ignea aerial parts extract on ulcer index and preventive index}

Oral administration of absolute ethanol induced gross lesions in the gastric lumen of rats with markedly high ulceration index. C. ignea gavaging prior to ethanol administration showed improved protection against ulceration degree. As shown in Fig. 3, both doses of $C$. ignea extract significantly reduced gastric ulcer index. The improvement in gastric ulcer index was more pronounced in C. ignea pretreated group than in ranitidine group. The preventive index recorded 90.49 and $88.89 \%$ for 250 and $500 \mathrm{mg} / \mathrm{kg}$ of C. ignea, respectively.

\section{Effect of $C$. ignea aerial parts extract on gastric secretion indices}

Ethanol administration caused significant decrease in $\mathrm{pH}$ value by $34.17 \%$ with a corresponding significant increase in gastric volume of gastric content by 20 -folds compared to control group. Treatments with $C$. ignea extract $(250$ and $500 \mathrm{mg} / \mathrm{kg})$ produced significant increase in $\mathrm{pH}$ value by 17.73 and $29.91 \%$ associated with significant decrease in gastric volume by 38.78 and $27.73 \%$, respectively as compared to ulcerated rats (Table 3). Simultaneously ethanol administration brought a significant decrease in pepsin activity of gastric juice in the ulcerated rats by $66.09 \%$ when compared with the normal control. Pepsin activity was significantly

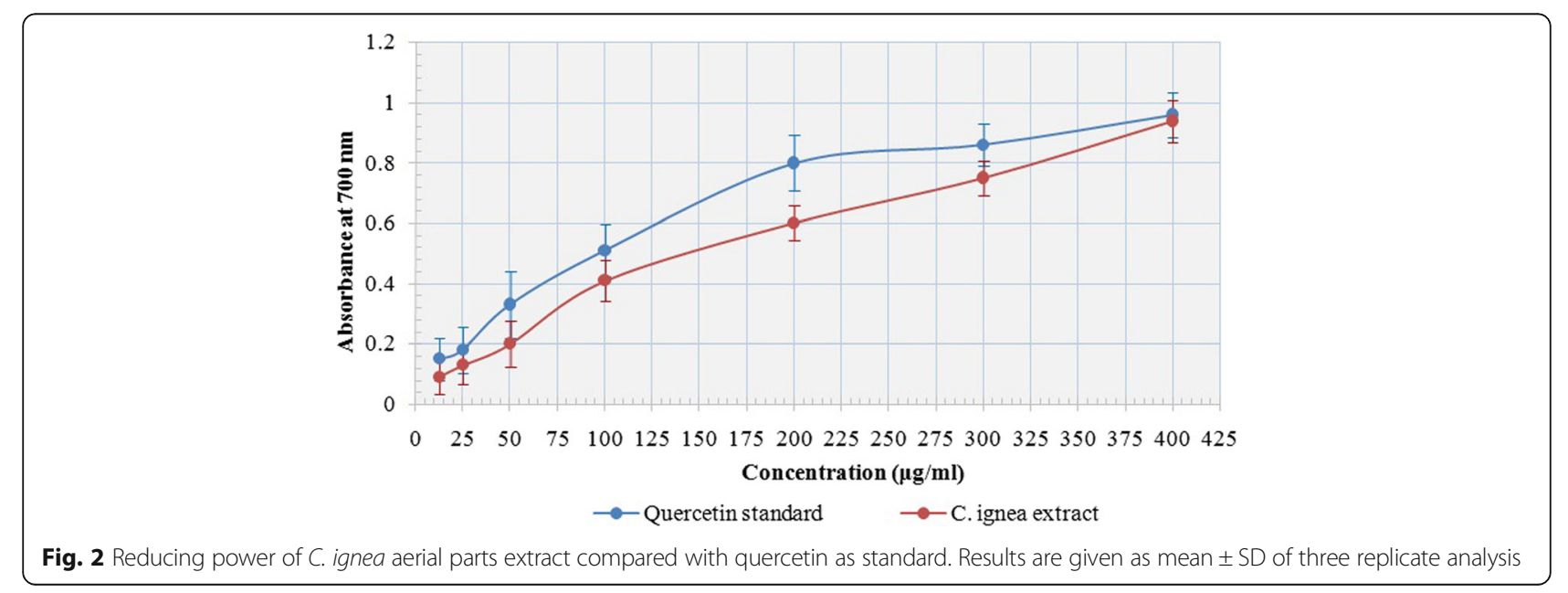


Table 2 Effect of $C$. ignea aerial parts extract on the liver and kidney function tests

\begin{tabular}{llllll}
\hline Groups & ASTIU/L & ALTIU/L & ALPIU/L & Ureamg/dl & Creatininemg/dl \\
\hline Control & $38.75 \pm 8.37$ & $7.50 \pm 3.06$ & $59.37 \pm 14.62$ & $47.09 \pm 9.08$ & $0.58 \pm 0.24$ \\
C. ignea 250 & $46.00 \pm 8.10$ & $8.75 \pm 7.56$ & $64.08 \pm 17.05$ & $46.00 \pm 8.10$ & $0.69 \pm 0.17$ \\
C. ignea 500 & $38.25 \pm 17.51$ & $9.50 \pm 4.62$ & $55.02 \pm 8.45$ & $43.25 \pm 13.10$ & $0.67 \pm 0.24$ \\
\hline
\end{tabular}

Data are represented by means for six rats \pm SD in each group

increased after treatment with 250 and $500 \mathrm{mg} / \mathrm{kg}$ of $C$. ignea extract by 19.25 and $62.12 \%$, respectively, compared to ulcerated rats.

Effect of $C$. ignea aerial parts extract on serum tumor necrosis factor-alpha, gastric mucosal myeloperoxidase activity and nitric oxide content

As shown in Fig. 4, TNF- $\alpha$ level and MPO activity were significantly increased in the ethanol group by 58.39 and $180.20 \%$, respectively, conversely, NO was significantly decreased by $40.30 \%$ as compared to the normal group. On the other hand, TNF- $\alpha$ and MPO significantly reduced by 17.6 and $54.08 \%$, respectively in ulcerated group pretreated with $250 \mathrm{mg} / \mathrm{kg}$ of extract in comparing with ethanol group. However, NO content was insignificantly affected. Pre-treatment with $C$. ignea at dose of $500 \mathrm{mg} / \mathrm{kg}$ showed significant improvement in TNF$\alpha$, MPO and NO by $27.20,47.81$ and $32.78 \%$ respectively. It is worth mentioning, improvement in MPO activity was more obvious in groups treated with $C$. ignea extract than in the animals treated with ranitidine.

\section{Effect of $C$. ignea aerial parts extract on gastric} antioxidants and MDA

In the present study, ulcerated rats recorded significant decrease in gastric CAT (37.13\%), SOD (54.46\%), GSHPx (18.06\%), GSH (57.13\%), contents, and typically showed significant increase in MDA level (1.77 fold) as compared to normal group. On the other hand, pretreatment with C. ignea extract at dose of $250 \mathrm{mg} / \mathrm{kg}$ significantly increased CAT, SOD, GSH-Px, GSH contents by $47.54,54.46,14.6,65.24 \%$, respectively, and significantly decreased MDA level by $41.10 \%$ as compared to ethanol group. Pre-treatment with $C$. ignea extract at dose of $500 \mathrm{mg} / \mathrm{kg}$ recorded significant improvement in all antioxidant markers with almost highest improvement percentages. It showed improvement by $69.34,15.89,77.75,46.78 \%$ for SOD, GSH-Px, GSH and MDA respectively as compared to ulcerated rats. However, CAT enzyme recorded $44.60 \%$ improvement only (Fig. 5).

\section{Pathological findings on the gastric mucosa Macroscopical findings}

The macroscopic examination for stomach of the control rats showed completely healthy pink color gastric mucosa with normal mucosal thickening (Fig. 6a). The ethanol treated group grossly exhibited exaggerated tissue reactions as; severe dark red submucosal hemorrhagic strikes with different sizes associated with mucosal thickening (Fig. 6b1, b2). The ranitidine treated group revealed that; the hemorrhagic vascular response became negligible but the mucosa still highly congested and swollen (Fig. 6c). Groups pretreated only with $C$.

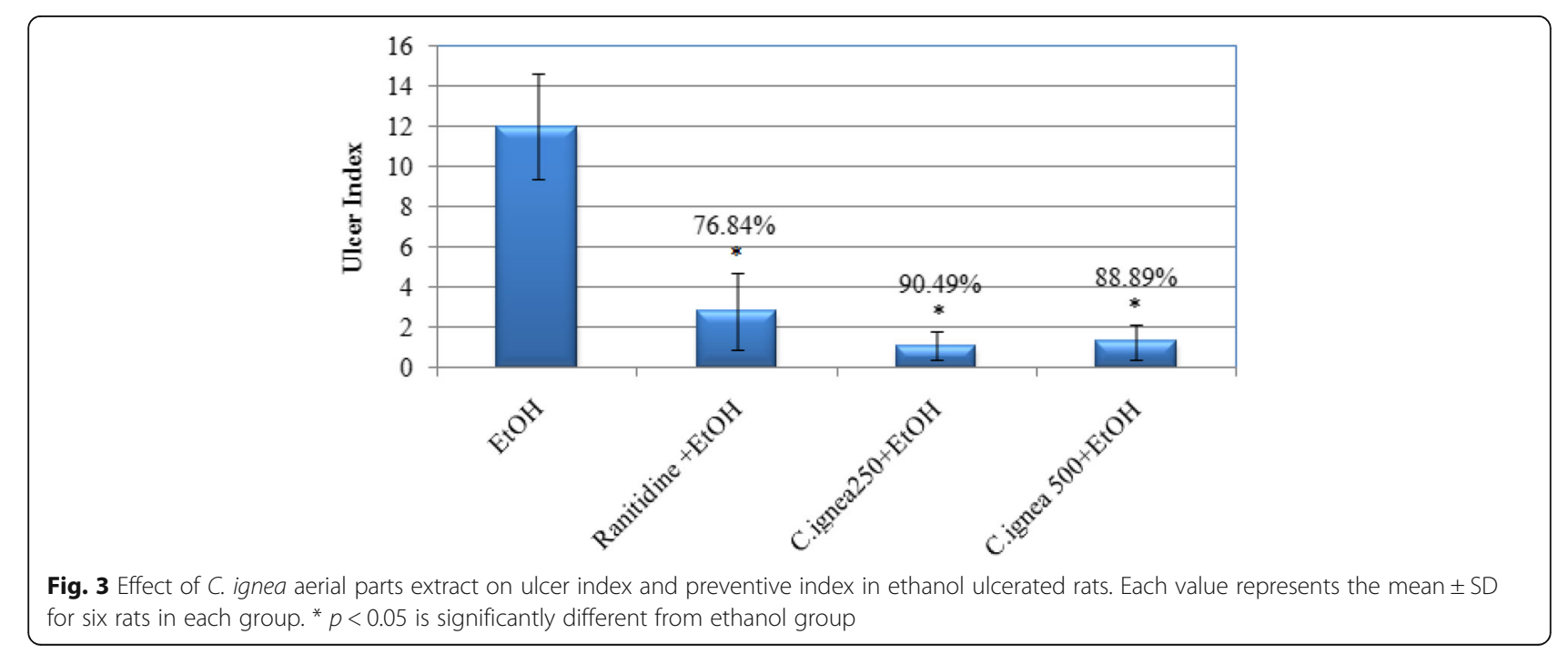


Table 3 Effect of $\mathrm{C}$. ignea aerial parts extract on $\mathrm{pH}$, volume and pepsin activity of gastric juice in various experimental groups

\begin{tabular}{llll}
\hline Groups & Gastric pH & Gastric Volume $(\mathrm{mL})$ & Pepsin activity $(\mathrm{U} / \mathrm{mL})$ \\
\hline Control & $7.11 \pm 1.99$ & $0.12 \pm 0.02$ & $2997.20 \pm 213.84$ \\
EtOH & $4.68 \pm 0.58^{\mathrm{a}}$ & $2.63 \pm 0.63^{\mathrm{a}}$ & $1016.33 \pm 218.03^{\mathrm{a}}$ \\
Ranitidine $+\mathrm{EtOH}$ & $6.12 \pm 1.86^{\mathrm{ab}}$ & $1.58 \pm 0.39^{\mathrm{ab}}$ & $1382.33 \pm 235.42^{\mathrm{ab}}$ \\
C. ignea 250 & $6.75 \pm 0.97^{\mathrm{b}}$ & $0.20 \pm 0.14^{\mathrm{b}}$ & $2928.83 \pm 293.80^{\mathrm{b}}$ \\
C. ignea $250+\mathrm{EtOH}$ & $5.51 \pm 1.93^{\mathrm{ab}}$ & $1.61 \pm 0.34^{\mathrm{ab}}$ & $1212.00 \pm 369.84^{\mathrm{a}}$ \\
C. ignea 500 & $6.87 \pm 0.83^{\mathrm{b}}$ & $0.15 \pm 0.04^{\mathrm{b}}$ & $3148.75 \pm 452.45^{\mathrm{b}}$ \\
C. ignea $500+\mathrm{EtOH}$ & $6.08 \pm 1.73^{\mathrm{ab}}$ & $1.91 \pm 0.61^{\mathrm{ab}}$ & $1647.76 \pm 311.09^{\mathrm{ab}}$ \\
\hline
\end{tabular}

Data are represented by means \pm SD for six rats in each group. Statistically significant difference is expressed at $p<0.05 .{ }^{\text {a }}$ significantly different from normal control group, ${ }^{b}$ significantly different from ethanol group

ignea extract at both doses showed no toxic or deteriorating effects on the gastric mucosa of the treated rats as; Normal non congested gastric mucosa with normal thickening were appeared (Fig. 6d, f). Rats pretreated with $C$. ignea extract at both doses before ethanol intoxication exhibited good protective level of $C$. ignea extract against ethanol effects as; mucosa color appeared normal pink with no thickening, also hemorrhages and congestion have not been noticed (Fig. 6e, g).

\section{Histopathological findings}

Control rats showed that; the villi of gastric mucosa were intact with no signs of hemorrhages or congestion; also there is no exfoliation in the mucosal epithelium (Fig. 7a).
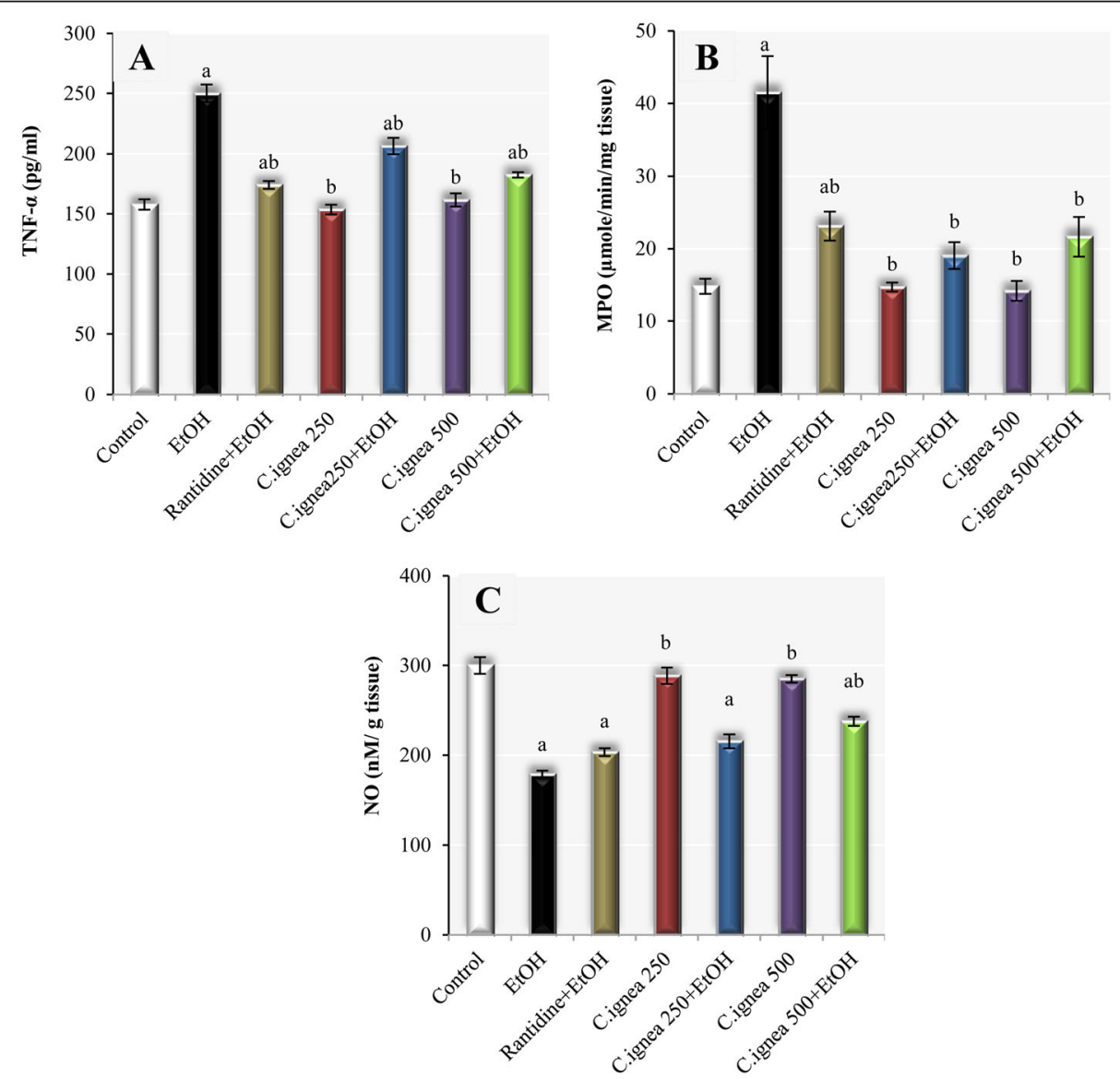

Fig. 4 Effect of C. ignea aerial parts extract on (a): serum TNF-a, (b): gastric MPO and (c): gastric NO in various experimental groups. Each value represents the mean \pm SD for six rats in each group. Statistically significant difference is expressed at $p<0.05 .{ }^{a}$ significantly different from normal control group, ${ }^{b}$ significantly different from ethanol group 

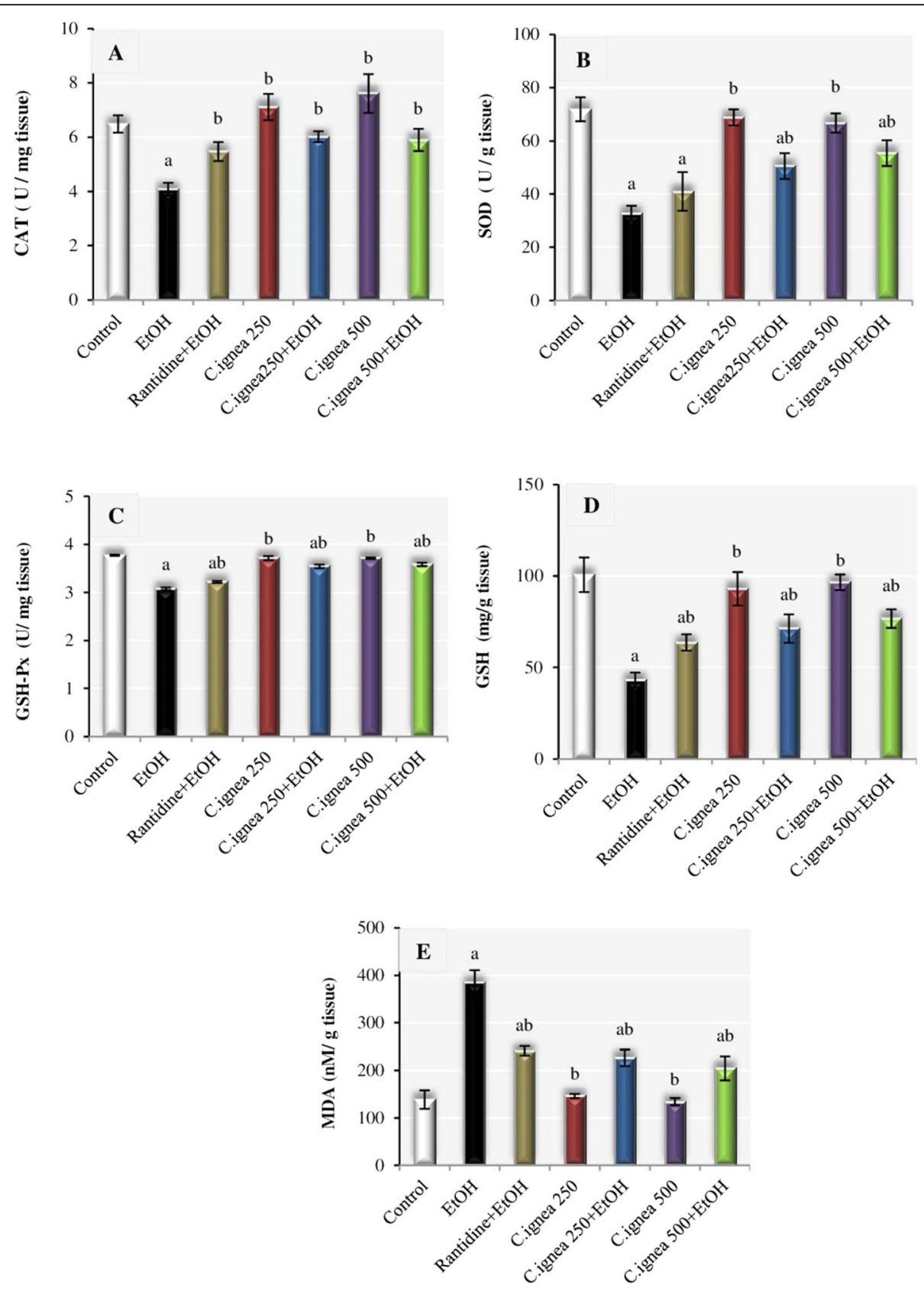

Fig. 5 Effect of C. ignea aerial parts extract on (a): CAT, (b): SOD, (c): GSH-Px, (d): GSH, (e): MDA in gastric tissue of various experimental groups. Each value represents the mean \pm SD for six rats in each group. Statistically significant difference is expressed at $p<0.05 .{ }^{a}$ significantly different from normal control group, ${ }^{b}$ significantly different from ethanol group

The ethanol treated group showed multifocal edema and mononuclear infiltration of inflammatory cells in the submucosal area. Moreover severe inter-villus hemorrhages associated with severe exfoliations in the mucous cells of the gastric mucosa (Fig. $7 b_{1}$ ). Some other areas of gastric mucosa exhibited severe coaggulative necrosis (Fig. $7 \mathrm{~b}_{2}$ ). The ranitidine treated group revealed that; the extravasation of RBCs in the core of gastric villi among the intervillus spaces became negligible. More over the desquamation of the mucous cells of the gastric mucosa and complete separation in the pyloric glands are still pronounced even with the ranitidine treatment (Fig. 7c). Groups pretreated only with $C$. ignea extract at both doses did not show any pathological changes or deteriorations on the gastric tissue (Fig. $7 \mathrm{~d}$, f). In ulcerated rats pretreated with $C$. ignea extract at both doses before ethanol intoxication; the gastric mucosa returned back again to normal intact mucosa with no hemorrhages 


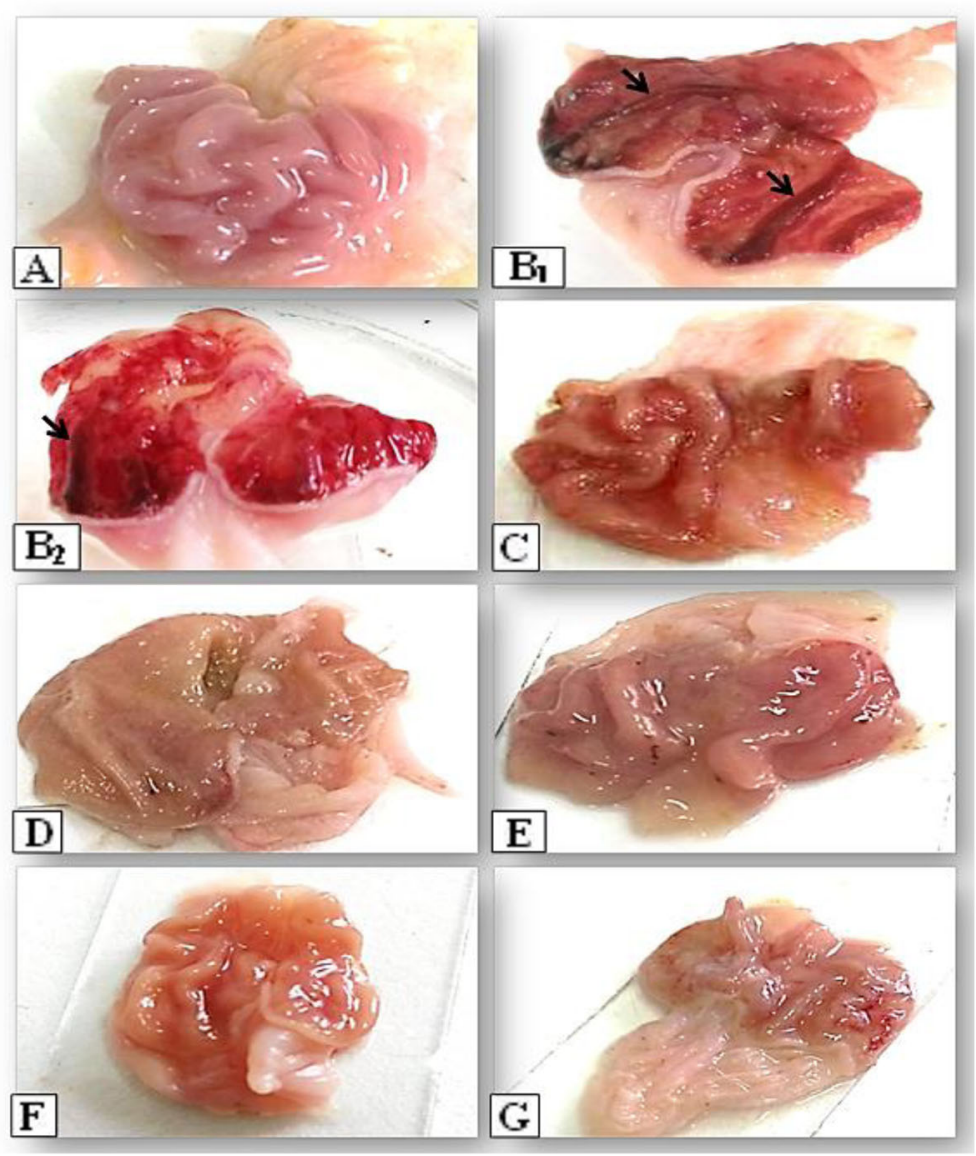

Fig. 6 Photograph of rat stomach showing protective effect of $C$. ignea aerial parts extract on the ethanol induced gastric ulceration in rat exposed to an experimental model as; Control (a), EtOH (b), Ranitidine (c), C. ignea $250 \mathrm{mg} / \mathrm{kg}$ (d), EtOH + C. ignea $250 \mathrm{mg} / \mathrm{kg}$ (e), C. ignea 500 $\mathrm{mg} / \mathrm{kg}(\mathbf{f}), \mathrm{EtOH}+\mathrm{C}$. ignea $500 \mathrm{mg} / \mathrm{kg}(\mathbf{g})$. a showed normal intact gastric mucosa. $\mathbf{b}_{\mathbf{1}}$ and $\mathbf{b}_{\mathbf{2}}$ revealed severe dark red submucosal hemorrhagic strikes (black arrows). In (c) congestion in gastric mucosa appeared. In ( $\mathbf{d}$ and $\mathbf{f}$ ) the gastric mucosa exhibited normal gross appearance with slight hyperemia and normal thickening in mucosa. In (e and $\mathbf{g}$ ) the gastric mucosa returned back to normal gross appearance with no lesions of hemorrhages or congestion

or congestion. No desquamation in pyloric glands (Fig. 7e, g).

\section{Discussion}

Alcohol consumption has been considered as a leading cause of gastric ulcer in humans; hence, researchers used the animal model of gastric injury induced by ethanol to simulate conditions that humans may be exposed, to study the antiulcer efficacy of natural products or new therapeutics intended to be used for gastric protection [4]. Oral administration of absolute ethanol in the animal model is destructive to stomach tissue, since it penetrates rapidly and easily into the gastric mucosa, producing gastric lesions [33]. Such lesions characterized by extensive submucosal edema, hemorrhage, desquamation of epithelial cells and infiltration of inflammatory cells, which are typical characteristics of alcohol injury in humans $[34,35]$.
The current study was designed for the first time, to study gastroprotective effect of aqueous ethanolic extract of $C$. ignea aerial parts against ethanol-induced gastric ulcer in comparison to ranitidine, which is widely approved and used for gastric ulcer treatment. This study is based on our phytochemical screening of this extract which revealed the presence of flavonoids, tannins, triterpenoids and saponin. These phytoconstituents, particularly flavonoids and tannins, were previously established to be among the possible cytoprotective agents involved in reducing gastric ulcer [36, 37].

In the present study, a high degree of ulceration was observed in rats treated with absolute ethanol. This was clearly confirmed by macroscopical and histopathological findings which revealed severe hemorrhage, appeared as severe congestion in the lamina propria submucosa and inter-villus extravasation of RBCs extended among the mucosal villi of the gastric tissue. These findings could be due to ethanol toxicity which 


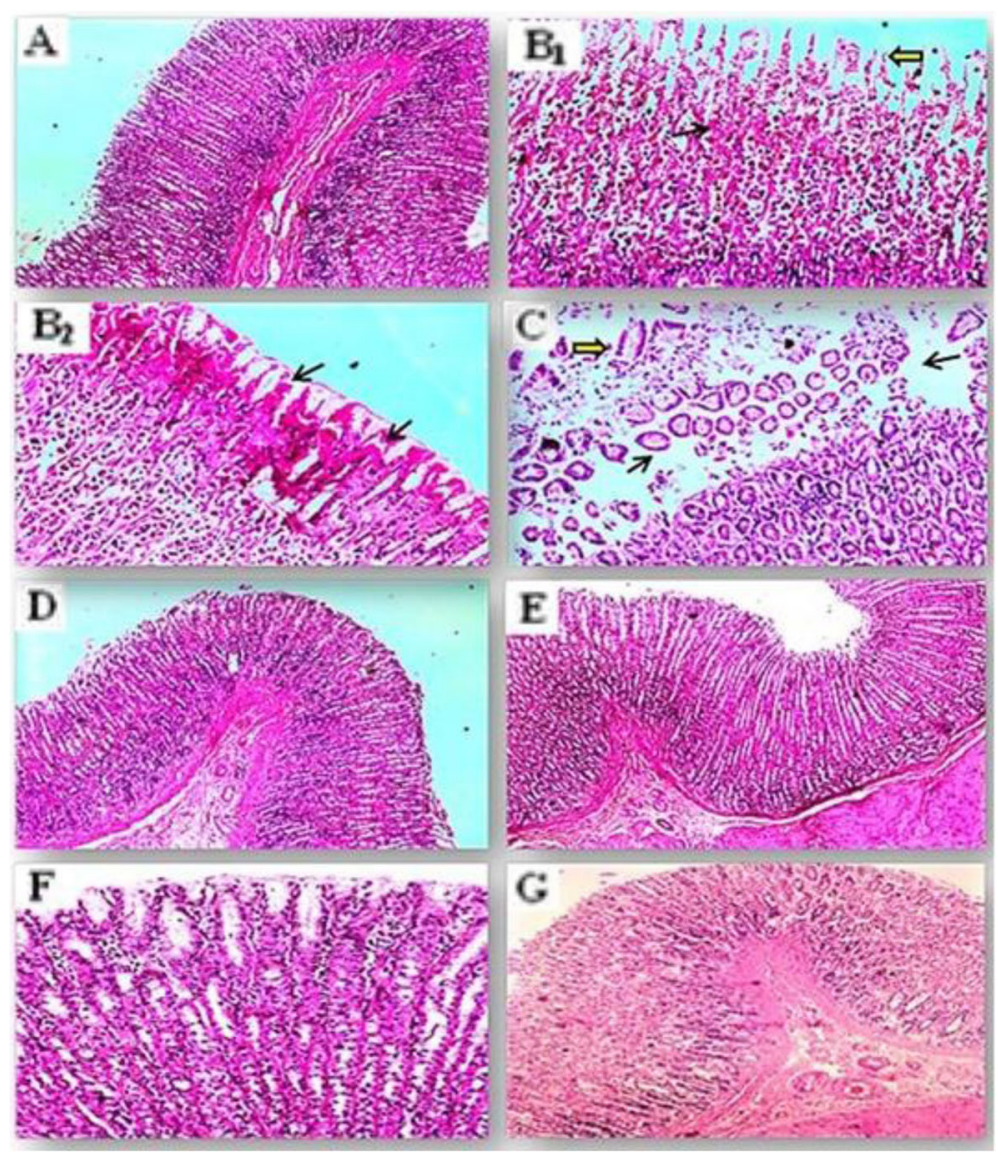

Fig. 7 Photomicrograph from stomach tissues for the protective effects of $C$. ignea aerial parts extract against ethanol induced gastric ulceration in rats. Histopathological tissue sections were stained with H\&E stain. In control rats; gastric mucosa showed intact villi with no hemorrhages or exfoliations $(\mathbf{a} \times 100)$. EtOH group; showed severe intervillus hemorrhages in gastric mucosa (black arrow) accompanied with severe desquamations in mucous cells (yellow arrow) $\left(\mathbf{b}_{\mathbf{1}} \times 200\right)$. Severe coaggulative necrosis in gastric villi (black arrows) was noticed $\left(\mathbf{b}_{\mathbf{2}} \times 200\right)$. In Ranitidine group; mucous cell desquamations of gastric villi (yellow arrow) and pyloric glands (black arrows) are pronounced (c × 100). In C. ignea $250 \mathrm{mg} / \mathrm{kg}$ and $500 \mathrm{mg} / \mathrm{kg}$ groups respectively the gastric tissue is histologically normal (d and $\mathbf{f} \times 100$ ). EtOH + C. ignea $250 \mathrm{mg} / \mathrm{kg}$ and EtOH + C. ignea $500 \mathrm{mg} / \mathrm{kg}$ groups; the lining epithelium of the gastric mucosa showed no exfoliations in the mucous cell, also no submucosal hemorrhages (e and $\mathbf{g} \times 100)$

causes decrease in the coagulopathy process which leads to the continuity of hemorrhage [38]. Hu et al. [39] reported that hemorrhagic shock induced by ethanol toxicity in lab animals is followed by alterations in the level of some pro-inflammatory and inflammatory mediators. Moreover, severe coaggulative necrosis was observed in some areas of gastric mucosa of ethanol treated rats. This result is in accordance with Liu et al. [4] and Li et al. [40], who stated that ethanol administration could induce gastric micro-vessel disturbance and blood flow stasis which finally lead to necrotic gastric injury. Pretreatment of rats with $C$. ignea extract significantly reduced the ulcer index at both doses compared to ulcerated group. Moreover, ulcerated animals pre-treated with $C$. ignea showed a better reduction in ulcer index than the standard drug ranitidine, indicating that $C$. ignea could be valuable in healing gastric ulcer. This result is in line with the study of Abebaw et al. [41], who reported similar effect for Osyris quadripartite Decne extract as compared to ranitidine.

Lüllmann et al. [42] stated that elevated concentration of the hydrogen ion is an aggressive factor facilitating gastric damage via decreasing $\mathrm{pH}$ in gastric juice. The present study showed significant reduction in gastric $\mathrm{pH}$ level in ethanol treated rats comparing to normal control group. $C$. ignea pre-treatment in ethanol-ulcerated groups significantly improved gastric $\mathrm{pH}$ levels with simultaneous decreases in gastric secretion in comparison to ethanol group. The efficiency of $C$. ignea extract in increasing gastric $\mathrm{pH}$ could be attributed to the presence of flavonoids in the extract. According to Zhao et al. [43] and Liu et al. [44], flavonoids have a main role in the mechanism of gastroprotection by rising $\mathrm{pH}$ of gastric juice. Moreover, our results showed that pre-treatment with $C$. ignea extract had similar effects on gastric $\mathrm{pH}$ as the reference ranitidine drug, which has a great ability to decrease stomach acid 
production and neutralize stomach acidic environment. Furthermore, our study showed that, ethanol ulcerated rats have significant reduction in pepsin activity in comparing to normal group and this is in agreement with Puurunen [45] who clarified that, high concentrations of ethanol can reduce peptic activity due to its ability to inhibit pepsinogen activation to pepsin. On the other hand, C. ignea pretreatment improved pepsin activity in gastric secretion in dose dependent manner, indicating that $C$. ignea extract has the ability to regulate ethanol effect on peptic activity.

Inflammatory response is one of the characteristics of gastric ulcer which promotes gastric mucosal injury through the migration of macrophages and leukocytes into the ulcerated and the surrounding areas [46]. TNF$\alpha$ is a major pro-inflammatory cytokine released from migrated macrophages during inflammation [47]. It stimulates neutrophil infiltration in gastric inflamed areas [48] and suppresses the gastric microcirculation around ulcerated mucosa and delays gastric ulcer healing [49]. The present data indicated that ethanol administration induced inflammatory response as evidenced by the marked increase in serum level of TNF- $\alpha$ as compared to control group. This result is consistent with previous reports of Li et al. [40] and El-Hussieny et al. [50] who reported an increase in gastric tissue proinflammatory cytokines due to ethanol administration. On the other hand, a dose-dependent reduction in TNF$\alpha$ level was observed in the ulcerated groups pretreated with $C$. ignea, and this may be attributed to its antiinflammatory effect. This result was confirmed by our histopathological findings which revealed decreased inflammatory responses by $C$. ignea pre-treatment.

Increased neutrophils infiltration into the gastric mucosa due to ethanol administration is assessed by elevation of the gastric MPO activity released from neutrophils [51, 52]. This was observed in the present work by marked increase in MPO activity in the stomach of rats treated with ethanol. Inhibition of neutrophil infiltration into ulcerated gastric tissues is a vital anti-inflammatory mechanism by which anti-ulcer agents can improve the healing process of gastric ulcer and protect against it [53]. Pre-treatment with $C$. ignea extract in ulcerated rats caused a significant and dose dependent reduction in neutrophil infiltration into the gastric mucosa as evidenced by suppression of MPO activity, demonstrating its anti-ulcer effect.

Nitric oxide, derived from constitutive nitric oxide synthase, is a vital endogenous mediator of mucosal defense and plays a significant role in the maintenance of normal gastric mucosal integrity [54]. This role of NO may be due to its ability to reduce neutrophil infiltration [55] and to influence blood flow in gastric tissues during the healing process of gastric ulcer [56]. In the present study, ethanol ulcerated group showed significant reduction in gastric NO levels in comparing to control group.
This finding is in accordance with Goswami et al. [57] and Nordin et al. [58]. On the other hand, ulcerated rats pre-treated with $C$. ignea displayed marked increase in NO level, indicating its anti-ulcer efficacy. According to Abdulla et al. [59] keeping normal levels of nitric oxide is one of the main mechanisms used to protect gastric mucosa against harmful effects of ethanol.

Laine et al. [60] stated that reactive oxygen species (ROS) generated by neutrophils in gastric mucosa has a critical role in the gastric mucosal injury. Later, $\mathrm{Al}$ Rashdi et al. [61] and Kan et al. [62] reported that elevated production of ROS and depletion of antioxidants are involved in the pathophysiology and development of ethanol-induced gastric ulcer. According to $\mathrm{Yu}$ et al. [63], accumulation of ROS leads to lipid peroxidation as a result of their reaction against cell membrane. Our data revealed that, ethanol administration significantly reduced the activity levels of antioxidant enzymes (CAT, SOD and GSH-Px) and increased the concentration of MDA with concomitant depletion in GSH concentration in the gastric tissue of ethanol group, this is in the same line with the previous studies of Sidahmed et al. [64]. On the other hand, pre-treatment of $C$. ignea extract in ulcerated groups has a great efficacy in preventing free radical mediated oxidative damage by enhancing the activity of antioxidant enzymes (CAT, SOD and GSH-Px) and restoring the depleted GSH levels together with reducing MDA levels. This antioxidant effect of the $C$. ignea extract could be attributed to its strong free radical scavenging activity due to the presence of a significant amount of, the powerful antioxidants, flavonoids and phenolic compounds. This is consistent with Mei et al. [53] who established that one of the mechanisms responsible for the healing of ulcer is scavenging of ROS. Our study showed that $C$. ignea extract had strong antioxidant effect, which is comparable to that of ranitidine. Ahmadi et al. [65] previously reported that therapeutic effect of ranitidine on ulcer could be related to its antioxidant capacity through oxidative stress reduction mediated by scavenging of hydroxyl radical.

\section{Conclusions}

The results of the present study demonstrated that the aqueous ethanolic extract of $C$. ignea aerial parts at both doses attenuated ethanol-induced gastric ulcer through its antioxidant and anti-inflammatory effects. This gastroprotective efficiency of $C$. ignea aerial parts extract could be possibly attributed to the presence of wealthy phytoconstituents as total polyphenols, flavonoids and tannins. Therefore, C. ignea could be used as a promising anti-ulcer agent in the treatment of gastric ulcers due to its comparable anti-ulcer effect to that of ranitidine. However, further researches should be taken to further explore the underlying mechanisms of action. 


\section{Abbreviations}

ALP: Alkaline phosphatase; ALT: Alanine transaminase; AST: Serum aspartate transaminase; CAT: Catalase; GSH: Reduced glutathione; GSH-Px: Glutathione peroxidase; H\&E: Hematoxylin and eosin; MDA: Malondialdehyde; MPO: Myeloperoxidase; NO: Nitric oxide; ROS: Reactive oxygen species; SOD: Superoxide dismutase; TNF-a: Tumor necrosis factor-alpha

\section{Acknowledgments}

Not applicable.

\section{Authors' contributions}

AMM and SKH proposed the research concept and designed the experimental model. AMM, NME, SKH and AEM performed the experimental work, provided reagents/materials necessary for experiments and interpreted the data and wrote the manuscript. ANH performed the extraction and the phytochemical studies. ESM carried out the in vitro studies. SMB collected plant samples and helped in the extraction. EAE analysed the data and corresponded the manuscript. All authors read and approved the final manuscript.

\section{Funding}

This work was funded by King Saud University, Riyadh, Saudi Arabia through Researchers Supporting Project (Project No. RSP-2019/52). Funding was obtained based on the proposed study and the funding bodies had no further role in data collection, analysis, interpretation or manuscript preparation

\section{Availability of data and materials}

All the data generated in this current work are included in the 'Result and Discussion'. Raw data supporting the findings of the current work are available from the corresponding author on reasonable request.

\section{Ethics approval and consent to participate}

All animal experimental procedures were carried out in line with the institutional guidelines of the Animal Care and Use Committee of National Research Centre, Cairo, Egypt, and with the Helsinki Declaration of 1975, as revised in 2000 and 2008. The experimental protocol was approved by the Research Ethical Committee of National Research Centre, Cairo, Egypt, Protocol number 16/164

\section{Consent for publications}

Not applicable

\section{Competing interests}

The authors declare that they have no competing interests.

\section{Author details}

${ }^{1}$ Department of Biochemistry, National Research Centre, Dokki, Cairo, Egypt. ${ }^{2}$ Department of Animal Reproduction and Artificial Insemination Research, National Research Centre, Dokki, Cairo, Egypt. ${ }^{3}$ Department of Phytochemistry and Plant Systematics, National Research Centre, Dokki, Cairo, Egypt. ${ }^{4}$ October University of Modern Sciences and Arts, 6th October City, Egypt. ${ }^{5}$ Bioproducts Research Chair, Zoology Department, College of Science, King Saud University, Riyadh, Kingdom of Saudi Arabia. ${ }^{6}$ Department of Chemistry of Natural and Microbial Products, National Research Centre, Dokki, Cairo, Egypt.

Received: 30 April 2019 Accepted: 19 November 2019 Published online: 02 December 2019

\section{References}

1. Li WF, Hao DJ, Fan T, Huang HM, Yao H, Niu XF. Protective effect of chelerythrine against ethanol-induced gastric ulcer in mice. Chem Biol Interact. 2014;208:18-27.

2. Heibashy MI, Mazen GM, Ibrahim MA. Efficacy and safety of some medical herbs on gastric ulcer induced by aspirin in rats. J Pharm Biol Sci. 2014;9(3): 19-27.

3. Franke A, Teyssen S, Singer MV. Alcohol-related diseases of the esophagus and stomach. Dig Dis. 2005;23(3-4):204-13.

4. Liu Y, Tian X, Gou L, Fu X, Li S, Lan N, Yin X. Protective effect of I-citrulline against ethanol-induced gastric ulcer in rats. Environ Toxicol Pharmacol. 2012;34(2):280-7.
5. World Health Organization. Traditional medicine strategy. 2014. http://www. searo.who.int/entity/health_situation_trends/who_trm_strategy_2014-2023. pdf?ua=1.

6. Saheed S, Olarewaju SA, Taofeeq G, Olatunde ST, Alanamu AA. Combined administration of Spondias mombin and Ficus exasperata leaf extracts stall indomethacin-mediated gastric mucosal onslaught in rats. Afr J Trad Complement Altern Med. 2015;12(1):45-51.

7. Padma TV. Ayurveda. Nature. 2005;436(7050):486 2005.

8. Agarwal P, Alok S, Verma A. An update on ayurvedic herb henna (Lawsonia inermis L.): A review. Int J Pharm Sci Res. 2014;5(2):330-9.

9. Bigoniya $P$, Singh K. Ulcer protective potential of standardized hesperidin, a citrus flavonoid isolated from Citrus sinensis. Rev Bras. 2014;24(3):330-40.

10. Florence AR, Sukumaran S, Joselin J, Brintha TS, Jeeva S. Phytochemical screening of selected medicinal plants of the family Lythraceae. Biosci Discov. 2015;6:73-82.

11. Graham SA, Freudenstein JV, Luker M. A phylogenetic study of Cuphea (Lythraceae) based on morphology and nuclear rDNA ITS sequences. Syst Bot. 2006;31(4):764-78.

12. Fernandes ER, Santos AL, Arruda AM, Vasques-Pinto LD, Godinho RO, Torres LM, Lapa AJ, Souccar C. Antinociceptive and anti-inflammatory activities of the aqueous extract and isolated Cuphea carthagenensis (Jacq.) JF Macbr. Rev Bras. 2002;12:55-6.

13. Krepsky PB, Farias MR, Côrtes SF, Braga FC. Quercetin-3-sulfate: a chemical marker for Cuphea carthagenensis. Biochem Syst Ecol. 2010;38(1):125-7.

14. Morales-Serna JA, García-Ríos E, Madrigal D, Cárdenas J, Salmón M. Constituents of organic extracts of Cuphea hyssopifolia. J Mex Chem Soc. 2011:55(1):62-4.

15. Floridata Plant Encyclopedia. 929 Cuphea ignea. https://floridata.com/Plants/ Lythraceae/Cuphea+ignea/929 (Updated 11 August 2003), 2015.

16. Bate-Smith EC. The phenolic constituents of plants and their taxonomic significance. I Dicotyledons Bot J Linn Soc. 1962;58(371):95-173.

17. Moustafa ES, Swilam NF, Ghanem OB, Hashim AN, Nawwar MA, Lindequist $U$, Linscheid MW. A coumarin with an unusual structure from Cuphea ignea, its cytotoxicity and antioxidant activities. Die Pharm. 2018;73(4):241-3.

18. Sofowora A. Medicinal plants and traditional medicine in Africa. Ibadan: Spectrum Books Ltd; 1993.

19. Hagerman A, Harvey-Mueller I. Makkar HPS. Vienna: Quantification of tannins in tree foliage-a laboratory manual FAO/IAEA; 2000. p. 21-4.

20. Žilić S, Serpen A, Akıllıoğlu G, Janković M, Gökmen V. Distributions of phenolic compounds, yellow pigments and oxidative enzymes in wheat grains and their relation to antioxidant capacity of bran and debranned flour. J Cereal Sci. 2012;56(3):652-8.

21. Brand-Williams W, Cuvelier ME, Berset CL. Use of a free radical method to evaluate antioxidant activity. LWT-Food Sci Technol. 1995;28(1):25-30.

22. Yen GC, Duh PD. Scavenging effect of methanolic extracts of peanut hulls on free radical and active oxygen species. J Agric Food Chem. 1994;42:629-32.

23. OECD Test Guideline 425. Guidelines for Testing of Chemicals. Guidelines 425, Acute Oral Toxicity-Up-and-Down Procedure, 2001.

24. Anson ML. The estimation of pepsin, trypsin, papain, and cathepsin with hemoglobin. J Gen Physiol. 1938;22(1):79-89.

25. Bradley PP, Priebat DA, Christensen RD, Rothstein G. Measurement of cutaneous inflammation: estimation of neutrophil content with an enzyme marker. J Invest Dermatol. 1982;78(3):206-9.

26. Yucel AA, Gulen S, Dincer S, Yucel AE, Yetkin Gl. Comparison of two different applications of the Griess method for nitric oxide measurement. J Exp Med. 2012;2(2):167-71.

27. Aebi H. Catalase in vitro. Methods Enzymol. 1984;105:121-6.

28. Minami M, Yoshikawa MA. A simplified assay method of superoxide dismutase activity for clinical use. Clin Chim Acta. 1979;92(3):337-42.

29. Necheles TF, Boles TA, Allen DM. Erythrocyte glutathione-peroxidase deficiency and hemolytic disease of the newborn infant. J Pediatr. 1968; 72(3):319-24

30. Beutler E. Improved method for determination of blood glutathione. J Lab Clin Med. 1963;61(5):882-8.

31. Lefevre G, Beljean-Leymarie M, Beyerle F, Bonnefont-Rousselot D, Cristol JP, Therond $\mathrm{P}$, Torreilles J. Evaluation of lipid peroxidation by assaying the thiobarbituric acid-reactive substances. Ann Biol Clin. 1998;56:305-19.

32. Suvarna K, Layton C, Bancroft J. Theory and practice of histological techniques. New York: Churchill Livingstone; 2012.

33. Sidahmed HM, Azizan AH, Mohan S, Abdulla MA, Abdelwahab SI, Taha MM, Hadi AH, Ketuly KA, Hashim NM, Loke MF, Vadivelu J. 
Gastroprotective effect of desmosdumotin C isolated from Mitrella kentii against ethanol-induced gastric mucosal hemorrhage in rats: possible involvement of glutathione, heat-shock protein-70, sulfhydryl compounds, nitric oxide, and anti-helicobacter pylori activity. BMC Complement Altern Med. 2013;13:183.

34. Park SW, Oh TY, Kim YS, Sim H, Park SJ, Jang EJ, Park JS, Baik HW, Hahm KB. Artemisia asiatica extracts protect against ethanol-induced injury in gastric mucosa of rats. J Gastroenterol Hepatol. 2008;23(6):976-84.

35. Silva Ml, Moura MA, de Aquino Neto MR, da Rocha TA, Rocha NF, de Carvalho AM, Macêdo DS, Vasconcelos SM, de Sousa DP, Viana GS, de Sousa FC. Gastroprotective activity of isopulegol on experimentally induced gastric lesions in mice: investigation of possible mechanisms of action. Naunyn Schmiedeberg's Arch Pharmacol. 2009;380(3):233-45.

36. Bhoumik D, Masresha B, Mallik A. Antiulcer properties of herbal drugs: a review. Int J Biomed Res. 2017:8(3):116-24.

37. Yahia M, Yahia M, Benhouda A, Benbia S, Khadraoui H. New gastroprotective activity of methanolic extracts of Hyoscyamus albus (Solanaceae) and Umbilicus rupestris leaves (Crassulaceae) against gastric mucosal injury induced by ethanol in rats. BioTechnol Indian J. 2017:13(1):122.

38. Lustenberger T, Inaba K, Barmparas G, Talving P, Plurad D, Lam L, Konstantinidis A, Demetriades D. Ethanol intoxication is associated with a lower incidence of admission coagulopathy in severe traumatic brain injury patients. J Neurotrauma. 2012;173:212-5.

39. Hu TM, Lee RP, Lee CJ, Subeq YM, Lin NT, Hsu BG. Heavy ethanol intoxication increases proinflammatory cytokines and aggravates hemorrhagic shock-induced organ damage in rats. Mediat Inflamm. 2013. https://doi.org/10.1155/2013/121786.

40. Li W, Huang H, Niu X, Fan T, Mu Q, Li H. Protective effect of tetrahydrocoptisine against ethanol-induced gastric ulcer in mice. Toxicol Appl Pharmacol. 2013;272(1):21-9.

41. Abebaw M, Mishra B, Gelayee DA. Evaluation of anti-ulcer activity of the leaf extract of Osyris quadripartita Decne (Santalaceae) in rats. J Exp Pharmacol. 2017:9:1-11.

42. Lüllmann H, Mohr K, Ziegler A, Bieger D. Color atlas of pharmacology. New York: Thieme, Stuttgart; 2000

43. Zhao X, Zhu K, Yi R, Peng D, Song JL. Total flavonoid from Ba lotus leaf protected the reserpine-induced gastric ulcer in mice. Biomed Res. 2017; 28(1):345-52.

44. Liu B, Feng X, Zhang J, Wei Y, Zhao X. Preventive effect of Anji white tea flavonoids on alcohol-induced gastric injury through their antioxidant effects in Kunming mice. Biomolecules. 2019;9(4):137. https://doi.org/10. 3390/biom9040137.

45. Puurunen J. Effect of ethanol on peptic activity in the rat stomach. Digestion. 1982;23(2):97-103.

46. Kang JW, Yun N, Han HJ, Kim JY, Kim JY, Lee SM. Protective effect of Flos Ionicerae against experimental gastric ulcers in rats: mechanisms of antioxidant and anti-inflammatory action. Evid-Based Complement Alternat Med. 2014;2014:596920.

47. Rozza AL, de Faria FM, Brito ARS, Pellizzon CH. The gastroprotective effect of menthol: involvement of anti-apoptotic, antioxidant and anti-inflammatory activities. PLoS One. 2014;9(1):e86686.

48. Aziz RS, Siddiqua A, Shahzad M, Shabbir A, Naseem N. Oxyresveratrol ameliorates ethanol-induced gastric ulcer via downregulation of IL-6, TNF-a, $\mathrm{NF}-\mathrm{KB}$, and COX-2 levels, and upregulation of TFF-2 levels. Biomed Pharmacother. 2019:110:554-60

49. Hasgul R, Uysal S, Haltas H, Akyol S, Yuksel Y, Gurel A, Armutcu F. Protective effects of Ankaferd blood stopper on aspirin-induced oxidative mucosal damage in a rat model of gastric injury. Toxicol Ind Health. 2014;30(10):888-95.

50. El-Hussieny EA, Mohamed EF, Attala NR, Abd El-Rahman FA. Gastroprotective effect of a new formulated milk tablet on ethanol-induced gastric mucosal injury in rats. Int J Adv Res. 2017:5(3):2374-88.

51. Al Asmari A, Al Shahrani H, Al Masri N, Al Faraidi A, Elfaki I, Arshaduddin M. Vanillin abrogates ethanol induced gastric injury in rats via modulation of gastric secretion, oxidative stress and inflammation. Toxicol Rep. 2016;3:105-13.

52. Yang C, Song Y, Wang H. Suppression of RAGE and TLR9 by ketamine contributes to attenuation of lipopolysaccharide-induced acute lung injury. J Investig Surg. 2017;30(3):177-86.

53. Mei X, Xu D, Xu S, Zheng Y, Xu S. Novel role of Zn (II)-curcumin in enhancing cell proliferation and adjusting proinflammatory cytokinemediated oxidative damage of ethanol-induced acute gastric ulcers. Chem Biol Interact. 2012;197(1):31-9.
54. Song JW, Seo CS, Kim TI, Moon OS, Won YS, Son HY, Kwon HJ. Protective effects of manassantin a against ethanol-induced gastric injury in rats. Bio Pharm Bull. 2016;39(2):221-9.

55. Ohta Y, Nishida K. Protective effect of L-arginine against stress-induced gastric mucosal lesions in rats and its relation to nitric oxide-mediated inhibition of neutrophil infiltration. Pharmacol Res. 2010;43(6):535-41.

56. Zhao X, Cheng Q, Qian Y, Yi R, Gu L, Wang S, Song JL. Insect tea attenuates hydrochloric acid and ethanol-induced mice acute gastric injury. Exp Ther Med. 2017;14(5):5135-42.

57. Goswami M, Kulshreshtha M, Rao CV, Yadav S, Yadav S. Anti-ulcer potential of Lawsonia inermis I. leaves against gastric ulcers in rats. J Appl Parm Sci. 2011;1:69-72.

58. Nordin N, Salama SM, Golbabapour S, Hajrezaie M, Hassandarvish P, Kamalidehghan B, Majid NA, Hashim NM, Omar H, Fadaienasab M, Karimian H, Taha H, Ali HM, Abdulla MA. Anti-ulcerogenic effect of methanolic extracts from Enicosanthellum pulchrum (king) Heusden against ethanol-induced acute gastric lesion in animal models. PLoS One. 2014;9(11):e111925.

59. Abdulla MA, Ali HM, Ahmed KA, Noor SM, Ismail S. Evaluation of the antiulcer activities of Morus alba extracts in experimentally-induced gastric ulcer in rats. Biomed Res. 2009:20(1):35-9.

60. Laine L, Takeuchi K, Tarnawski A. Gastric mucosal defense and cytoprotection: bench to bedside. Gastroenterology. 2008;135(1):41-60.

61. Al Rashdi AS, Salama SM, Alkiyumi SS, Abdulla MA, Hadi AH, Abdelwahab SI, Taha MM, Hussiani J, Asykin N. Mechanisms of gastroprotective effects of ethanolic leaf extract of Jasminum sambac against HCl/ethanol-induced gastric mucosal injury in rats. Evid-Based Complement Alternat Med. 2012; 2012:786426.

62. Kan J, Hood M, Burns C, Scholten J, Chuang J, Tian F, Pan X, Du J, Gui M. A novel combination of wheat peptides and fucoidan attenuates ethanolinduced gastric mucosal damage through anti-oxidant, anti-inflammatory, and pro-survival mechanisms. Nutrients. 2017;9(9):E978.

63. Yu T, Yang Y, Kwak YS, Song GG, Kim MY, Rhee MH, Cho JY. Ginsenoside Rc from Panax ginseng exerts anti-inflammatory activity by targeting TANKbinding kinase 1/interferon regulatory factor-3 and p38/ATF-2. J Ginseng Res. 2017:41(2):127-33.

64. Sidahmed HM, Hashim NM, Amir J, Abdulla MA, Hadi AH, Abdelwahab SI, Taha MM, Hassandarvish P, Teh X, Loke MF, Vadivelu J, Rahmani M, Mohan S. Pyranocycloartobiloxanthone a, a novel gastroprotective compound from Artocarpus obtusus Jarret, against ethanol-induced acute gastric ulcer in vivo. Phytomedicine. 2013;20(10):834-43.

65. Ahmadi A, Ebrahimzadeh MA, Ahmad-Ashrafi S, Karami M, Mahdavi MR, Saravi SS. Hepatoprotective, antinociceptive and antioxidant activities of cimetidine, ranitidine and famotidine as histamine $\mathrm{H} 2$ receptor antagonists. Fundam Clin Pharmacol. 2011;25(1):72-9.

\section{Publisher's Note}

Springer Nature remains neutral with regard to jurisdictional claims in published maps and institutional affiliations.
Ready to submit your research? Choose BMC and benefit from:

- fast, convenient online submission

- thorough peer review by experienced researchers in your field

- rapid publication on acceptance

- support for research data, including large and complex data types

- gold Open Access which fosters wider collaboration and increased citations

- maximum visibility for your research: over $100 \mathrm{M}$ website views per year

At BMC, research is always in progress.

Learn more biomedcentral.com/submissions 